\title{
Platelet-Eosinophil Interactions As a Potential Therapeutic Target in Allergic Inflammation and Asthma
}

\author{
Sajeel A. Shah, Clive P. Page and Simon C. Pitchford* \\ Sackler Institute of Pulmonary Pharmacology, Institute of Pharmaceutical Science, King's College London, London, \\ United Kingdom
}

OPEN ACCESS

Edited by:

Mats W. Johansson,

University of Wisconsin-Madison,

United States

Reviewed by:

Leo Koenderman,

Utrecht University, Netherlands

Tanya Maria Laidlaw,

Brigham and Women's Hospital,

United States

*Correspondence:

Simon C. Pitchford

simon.pitchford@kcl.ac.uk

Specialty section: This article was submitted to Pulmonary Medicine, a section of the journal

Frontiers in Medicine

Received: 04 May 2017

Accepted: 24 July 2017

Published: 08 August 2017

Citation:

Shah SA, Page CP and Pitchford SC (2017) Platelet-Eosinophil Interactions As a Potential

Therapeutic Target in Allergic Inflammation and Asthma.

Front. Med. 4:129.

doi: 10.3389/fmed.2017.00129
The importance of platelet activation during hemostasis is well understood. An understanding of these mechanisms has led to the use of several classes of anti-platelet drugs to inhibit aggregation for the prevention of thrombi during cardiovascular disease. It is now also recognized that platelets can function very differently during inflammation, as part of their role in the innate immune response against pathogens. This dichotomy in platelet function occurs through distinct physiological processes and alternative signaling pathways compared to that of hemostasis (leading to platelet aggregation) and is manifested as increased rheological interactions with leukocytes, the ability to undergo chemotaxis, communication with antigen-presenting cells, and direct anti-pathogen responses. Mounting evidence suggests platelets are also critical in the pathogenesis of allergic diseases such as asthma, where they have been associated with antigen presentation, bronchoconstriction, bronchial hyperresponsiveness, airway inflammation, and airway remodeling in both clinical and experimental studies. In particular, platelets have been reported bound to eosinophils in the blood of patients with asthma and the incidence of these events increases after both spontaneous asthma attacks in a biphasic manner, or after allergen challenge in the clinic. Platelet depletion in animal models of allergic airway inflammation causes a profound reduction in eosinophil recruitment to the lung, suggesting that the association of platelets with eosinophils is indeed an important event during eosinophil activation. Furthermore, in cases of severe asthma, and in animal models of allergic airways inflammation, platelet-eosinophil complexes move into the lung through a platelet P-selectin-mediated, eosinophil $\beta 1$-integrin activation-dependent process, while platelets increase adherence of eosinophils to the vascular endothelium in vitro, demonstrating a clear interaction between these cell types in allergic inflammatory diseases. This review will explore non-thrombotic platelet activation in the context of allergy and the association of platelets with eosinophils, to reveal how these phenomena may lead to the discovery of novel therapeutic targets.

Keywords: platelets, eosinophils, asthma, P-selectin, allergy, IgE

\section{INTRODUCTION}

Platelets are small, anuclear cell fragments that are essential for hemostasis. Activation of platelets during hemostasis leads to shape change, $\alpha$-granule, dense $\delta$-granule, and lysosomal $\lambda$-granule release, along with surface expression of adhesion molecules and receptors, leading to platelet aggregation and clot formation (1-3). In addition to these hemostatic responses, it is now understood that platelets 
contribute distinct functions to non-thrombotic processes such as innate immunity to pathogens, and inflammatory disorders where there is often no associated changes in hemostatic functions of platelets. The difference in platelet function in hemostasis compared with inflammation has led to the hypothesis that there is a dichotomy in platelet activation (4), which has recently been confirmed experimentally $(5,6)$. It is necessary to comprehend such a distinction when analyzing the relationship platelets have with eosinophils in the context of allergic inflammation and host defense.

Platelets express an array of physiologically relevant and functional receptors that might be considered relevant to the inflammatory response in asthma and allergic inflammation, including chemokine receptors (CCR1, CCR3, CCR4, and CXCR4 receptors) (7), immunoglobulin receptors (Fc $\gamma$ RI, Fc $\gamma$ RII, Fc $\gamma$ RIII; FceRI, FceRII, Fc $\alpha$ RI/CD89) (8-11), toll-like receptors (TLR2, TLR4, and TLR9) (12), and certain adhesion molecules (PSGL-1, P-Selectin, and ICAM-2) $(10,13)$. Platelets also store inflammatory mediators in granules that can be released on activation, such as platelet factor-4 (PF4, CXCL4) (14), interleukin-1 $\beta$ (IL-1 $\beta$ ) $(15,16)$, regulated upon activation normally T-cell expressed and secreted (RANTES, CCL5), and thymus activation regulated chemokine (CCL17) $(3,17)$. Therefore, platelets indeed possess the requisite components to behave as inflammatory cells, as has been demonstrated in allergic diseases including asthma, allergic rhinitis, and eczema. This short review will examine non-thrombotic platelet activation in asthma and allergic inflammation, and the association of platelets with eosinophils in these disease states, which are perhaps an inappropriate manifestation of interactions between platelets and eosinophils that occur as part of host defense against parasitic infections.

\section{PLATELETS IN ASTHMA AND ALLERGIC INFLAMMATION}

Evidence has suggested platelet activation occurs in allergic diseases since the 1970s (18). We refer the reader to recent extensive reviews on the implications of platelet activation in asthma and give a summary below $(19,20)$. Following bronchial provocation of patients with asthma, there is an increased release of platelet-specific chemokines, for example, PF4 and betathromboglobulin ( $\beta$-TG, CXCL7) (21), and mediators derived from platelets, for example, 5-hydroxytriptamine (5-HT) (22), free radical species (23), and RANTES (9). Thus, the activation of platelets in vivo from patients with asthma is demonstrated by the fact that ex vivo analysis of platelets from subjects with asthma have a diminished store of mediators, which has been linked to an apparent lack of in vitro responsiveness due to prior activation in vivo: the so-called "platelet exhaustion" $(24,25)$. Patients with asthma have also been reported to exhibit mild thrombocytopenia after allergen provocation (26-28) and to have shortened platelet lifespans in the circulation compared with healthy individuals (29), demonstrating that continuous platelet activation may occur as part of this disease. The mild thrombocytopenic effects observed within minutes after allergen exposure in patients with asthma suggests that platelets are recruited to the lungs $(26,28)$. Indeed, platelets are present in bronchoalveolar lavage fluid and in bronchial biopsies of patients with asthma. In particular, platelets are found in extravascular compartments and also in fibrous material within the airway luminal edge, indicating platelets have the ability to migrate into inflamed tissue $(30,31)$. Platelet chemotaxis toward inflammatory chemokines, formyl-methionyl-leucyl phenylalanine (fMLP), macrophage-derived chemokine (CCL22), and stromal cell-derived factor $1 \alpha\left(\right.$ SDF- $1_{\alpha}$, CXCL12) has been demonstrated in vitro, through $N$-formyl-peptide (32), CCR4 and CXCR4 receptor activation, respectively $(33,34)$. These migratory effects may well be attributed to the fact that platelets can release enzymes contributing to movement such as cathepsin $\mathrm{D}$, cathepsin $\mathrm{E}$, heparinase, and $\beta-\mathrm{N}$-acetylhexosaminidase and possess the necessary machinery to extend pseudopod-like processes and undergo actin cytoskeleton rearrangements, indicating that platelets have the mechanical capability to migrate in response to situations caused by allergic inflammation $(34,35)$.

\section{Platelets and Cellular Motility}

Indeed, platelets have been shown to undergo chemotaxis directly toward allergen in vitro and migration through lung tissue in vivo via an IgE-/FceRI-dependent mechanism (11). The induction of cellular chemotaxis by allergen appears to be atypical of how other molecules induce chemotaxis via GPCRs, although chemotaxis can be induced by structurally very varied molecules. It has been reported that basophils $(36)$, mast cells $(37,38)$, and eosinophils (39) can undergo chemotaxis to specific allergens. These studies investigated a range of allergens and laboratory antigens and reported that cellular chemotaxis toward allergen was also IgE and FceRI dependent (11, 37, 38), while others reported an affect via formyl peptide receptors (40). Clearly, the molecular mechanisms are not as well understood as chemotaxis induced by via GPCR activation. It is also interesting that FceRI signaling can modify, or be modified by GPCRs, including certain chemokine receptors $(41,42)$. The significance of this is unknown with respect to cell motility. While it is speculative to consider whether platelet motility toward allergen might therefore modify eosinophil chemotaxis, platelets have recently been reported to be important for the intravascular crawling of neutrophils $(43,44)$, and platelet-dependent neutrophil chemotaxis to a range of chemokines in vitro $(5,45-48)$, and platelets might have a similar relationship with eosinophils.

\section{Platelets in Bronchoconstriction}

It has been postulated that the platelets found within the airways of patients with asthma could propagate disease progression via various mechanisms. In patients with asthma, platelets can become activated following exposure to allergens, endotoxins, pollutants, and inflammatory mediators (19). The consequence of this is unknown. However, in models of allergic airway inflammation in rabbits and guinea pigs, platelet depletion prevented bronchoconstriction induced by certain substances such as bradykinin and capsaicin $(49,50)$, but had no effect on direct acting spasmogens such as histamine, substance $\mathrm{P}$, and methacholine. Human platelets are able to produce a number of bronchoactive mediators within their granules such as histamine, 
serotonin, thromboxane $\mathrm{A}_{2}\left(\mathrm{TXA}_{2}\right)$, adenosine, 12-HETE, and cytotoxic compounds (19).

Thus, platelets that have accumulated within the lung may release stored spasmogens and affect the action of other spasmogens leading to bronchoconstriction. Furthermore, agents released by platelets might stimulate eosinophils in situ to cause eosinophil-dependent bronchoconstriction $(19,51,52)$.

\section{Airway Remodeling}

In bronchial asthma, chronic inflammation can alter the airway architecture that contributes to adverse effects on respiratory function. Platelet activation has been shown to persist long after the initial allergen challenge and outlasts the presence of platelet-leukocyte conjugates in the blood, displaying a potential role for platelets in chronic airway remodeling (28). Platelets produce mitogens such as $\mathrm{TXA}_{2}$, transforming growth factor- $\beta$, platelet-derived growth factor, epidermal growth factor, and vascular endothelial growth factor, which can have proliferative actions on cells located in the airways (19). Platelet depletion in a mouse model of allergic airways inflammation decreased epithelial thickening, smooth muscle thickening, and sub-epithelial reticular fiber deposition (53). Thus, platelet activation appears to play an important role in airway remodeling by release of extracellular matrix modifying enzymes and hypertrophic factors, causing smooth muscle hyperplasia and collagen deposition. While some of these events appeared to be independent of leukocyte activity (53), the association of platelets with eosinophil activation discussed in the following sections implies that eosinophil-associated remodeling events might be dependent on platelet activation.

\section{PLATELET-EOSINOPHIL INTERACTIONS FORM A PART OF HOST DEFENSE AGAINST PARASITE INFECTIONS}

Platelet participation is necessary during our immune defense against pathogens of bacterial, viral, and fungal origin (54), and platelet activation also occurs in immunity against parasites, for example, helminths (Schistosomiasis), protozoa (toxoplasmosis), and malaria (54-57). In particular, a role of eosinophils in helminth infections remains an important area of study $(58,59)$. There are therefore correlations in platelet and eosinophil activities, and that of their activation by IgE in IgE-dependent killing of schistosomes that are applicable to our understanding of the association between these two cell types in allergy $(23,58)$. While platelets express other immunoglobulin receptors (Fc $\gamma \mathrm{RI}$, Fc $\gamma$ RII, Fc $\gamma$ RIII; Fc $\alpha$ RI/CD89), the roles of these receptors in platelet responses to infection, and possible platelet effects on eosinophils have not been as extensively reported. Furthermore, it is possible that platelet-eosinophil interactions during host defense occur via non-immunoglobulin-associated activation pathways. We therefore discuss below a data set that is restricted to IgE/IgE receptor interactions as one example by which platelets and eosinophils can interact with each other, and which may have implications in allergic diseases. Human platelets express both high-affinity (8) and low-affinity (60) IgE receptors (FceR1 and
FceRII or CD23, respectively). The level of expression of FceR1 and CD23 are variable, and they are not found on all platelets from a given donor, platelet stimulation by IgE or allergen interactions can cause non-thrombotic platelet activation leading to release of cytotoxic mediators, such as reactive oxygen metabolites, free radicals, and catonic proteins $(8,61)$. While the physiological consequence of platelet-derived cytotoxic substances, compared to other cellular sources of the same or similar material is not known, the expression of IgE receptors on platelet surfaces was demonstrated to be important for host defense against parasitic infections as originally demonstrated in the seminal work of Capron and Joseph in the 1980s, who showed that IgE receptor stimulation of platelets was essential in killing certain types of parasites, by stimulating this generation and release of cytotoxic free radicals $(8,61)$. Various lines of enquiry have revealed that platelets can release chemokines in response to IgE stimulation (for example, RANTES and PF-4) that are potent toward eosinophils (62-65); and these also stimulate eosinophil free radical oxygen products (66). Platelets have been reported to release GM-CSF and thus inhibit eosinophil apoptosis, prolonging survival (67). Early studies related to the mechanism by which eosinophils engaged with Schistosoma mansoni revealed that selectin and Lewis X-related structures might act as coreceptors for eosinophil-mediated killing of worms (68). P-selectin mediates adhesion of platelets to eosinophils (69), and PSGL1 -P-selectin interactions between platelets and eosinophils can lead to CD18-dependent eosinophil stable adhesion (70). It is therefore of interest that there are perhaps parallels with how platelets enhance neutrophil responses to pathogens and NET formation via P-selectin interactions (19). Thus, it would appear that platelets have the capacity to enhance eosinophil functions against parasitic infections (see Figure 1).

The relationship between platelets and eosinophils is symbiotic. Eosinophils also release products that can potentially stimulate platelets, for example, platelet-activating factor (PAF) (71). Although the physiological consequences are unclear, an early in vitro investigation by the group of Gerald Gleich reported that eosinophil granule proteins, such as major basic protein $(\mathrm{MBP})$ and eosinophil peroxidase (EPO) are very potent at inducing platelet $\alpha$ granule ( $\beta$-TG), dense granule (5-HT), and lysosomal granule ( $\beta$ - $N$-acetylglucosaminidase) release, whereas eosinophil-derived neurotoxin and eosinophil cationic protein (ECP) had no effect (72). It was also noted that MBP and EPO stimulation of platelets was different in nature to thrombin stimulation (72). It is therefore of interest that a recent study reported that platelet aggregation was inhibited by eosinophil supernatant, and ECP in particular (73). The implications of platelet activation being induced by eosinophil-derived mediators on the one hand and inhibition of platelet aggregation to agonists by eosinophil-derived mediators on the other is difficult to interpret. It is possible that eosinophils activate or prime platelets for functions unrelated to aggregation, thereby revealing evidence for the "dichotomy in platelet function" (4). Alternatively, it is possible that different mediators derived from eosinophils promote selective functions of platelets, since there is an association of eosinophils with thrombi in patients with acute myocardial infarction $(74,75)$. However, the role of eosinophils in thrombosis, and a 


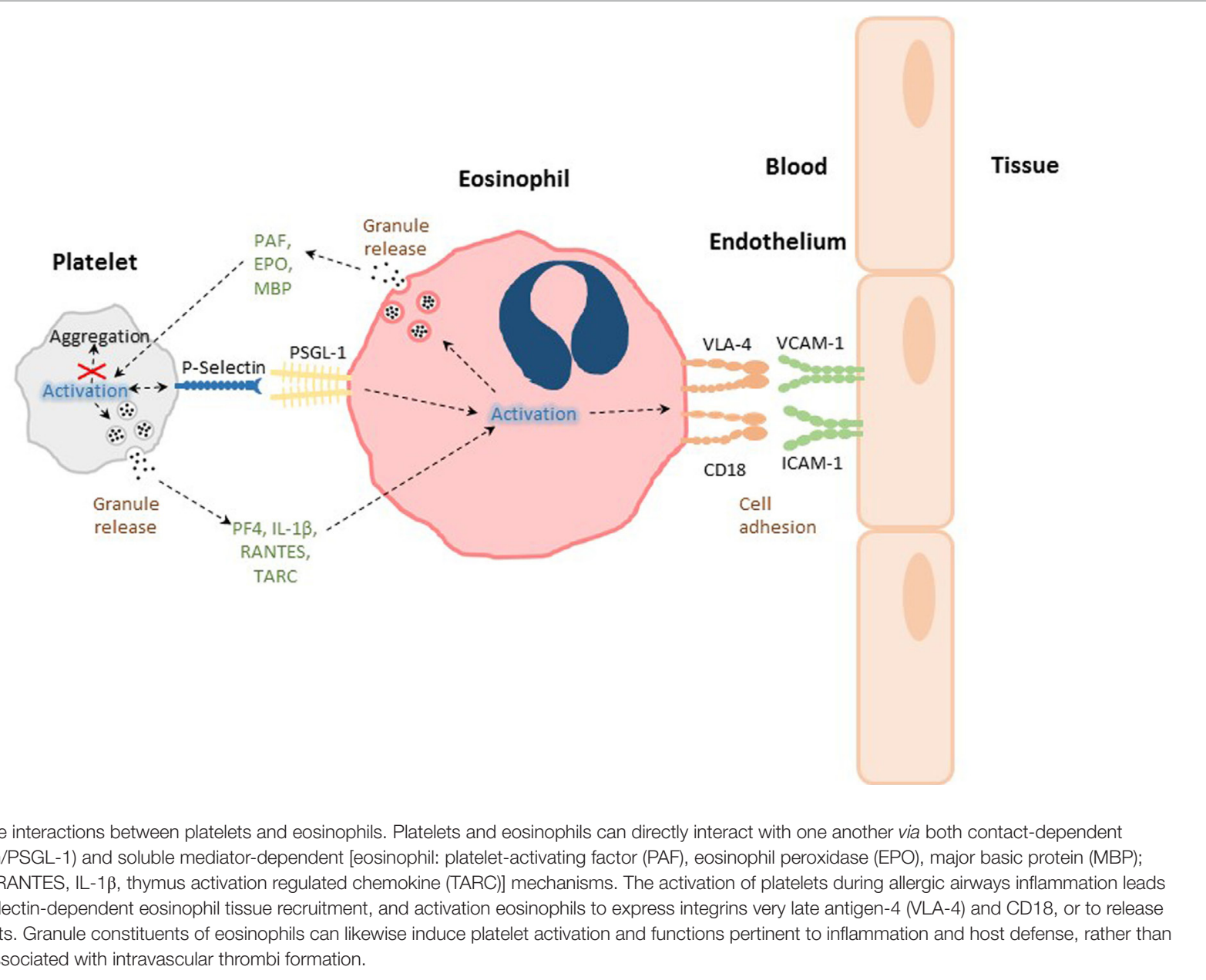

causal link to platelet activation (aggregation) has not been made, although patients with allergies have been reported to have less calcification of the major arteries, suggesting allergy might be protective (76).

\section{PLATELET-EOSINOPHIL INTERACTIONS IN ASTHMA AND ALLERGY}

Eosinophilic inflammation is associated with atopic asthma, rhinitis, and aspirin-induced exacerbated respiratory disease (AERD) (77-79), therefore the interactions between eosinophils and platelets that can occur during host defense may be important for the pathogenesis of these respiratory conditions. Lellouch-Tubiana and colleagues first demonstrated in an allergic guinea pig model of asthma that eosinophil infiltration into the lung is reduced when platelet numbers are depleted in the circulation using an anti-platelet antiserum (APAS) (80). These findings were later supported by data which showed that platelet depletion via APAS, caused a reduction in eosinophil infiltration, and decreased hyperresponsiveness into the lungs of allergic rabbits and mice $(49,81)$. Subsequently, correlations between eosinophil and platelet activity have been reported in patients with asthma. Nasal wash levels of ECP and P-selectin as measures of activation of eosinophils and platelets, respectively, revealed a positive association between eosinophils and platelets, which was negatively associated with asthma-related quality of life measurements (51). Furthermore, an association of platelets with eosinophils was reported in 1992, and more recently, staining of mixed leukocyte cytospins from whole blood revealed 5-25\% eosinophils attached to platelets from patients with mild or moderate asthma $(82,83)$, and in AERD (84) suggesting a possible role of platelets in human lung eosinophilia. While ex vivo measurements of circulating platelet-leukocyte (eosinophil) complexes cannot on their own be suggestive of a mechanism by which platelets influence eosinophil tissue recruitment, due to complexities of blood processing, the association between eosinophils and platelets does have functional consequences for recruitment, because eosinophils isolated from patients with asthma adhere to endothelial cells under flow conditions to a greater degree compared to eosinophils from healthy subject, and platelets promote this adhesion (85), and this important phenomenon is discussed below.

A role of platelet P-selectin-mediated events has been widely investigated in the evaluation of pulmonary eosinophil recruitment and activation, since platelets adhere to 
eosinophils via P-selectin/PSGL-1-dependent interactions, and $\mathrm{P}$-selectin is important for pulmonary leukocyte recruitment $(13,69,70,86-90)$. Specifically, the adhesion of platelets and eosinophils has been investigated in vitro, by comparing different stimuli that activate either eosinophils, platelets or both: fMLP, thrombin, and LPS $(91,92)$. A blocking antibody to P-selectin and fucoidan (a non-selective selectin antagonist) was reported to suppress the rossetting of platelets around eosinophils, while abciximab (integrin $\alpha \operatorname{IIb} \beta 3$ antagonist) and blocking anti-L-selectin antibody had no effect (92). Furthermore, the addition of aspirin had a rather minor effect on platelet-eosinophil rosettes, while WEB2170 (PAF receptor antagonist) and MK886 (an inhibitor of FLAP) actually increased the phenomenon (92).

The specific mechanisms behind platelet and eosinophil interactions are therefore due to surface expression of adhesion molecules on activated cells (see Figure 1). In a mouse model of allergic airways inflammation, P-selectin expression on platelets was critical in eosinophil recruitment to the lung, following allergen challenge. Platelet-depleted mice that had been sensitized and exposed to experimental allergen had reduced pulmonary eosinophil recruitment after transfusion of unstimulated platelets, when compared with transfusion with stimulated platelets expressing P-selectin (13). Johansson and colleagues have reported that eosinophils taken from the blood of patients with non-severe asthma have increased levels of surface associated platelets expressing P-selectin after whole-lung antigen challenge, and these were associated with increased $\alpha 4 \beta 1$-integrin very late antigen-4, but not $\alpha \mathrm{M} \beta 2$ integrin MAC-1 expression on a proportion of eosinophils (52). $\beta 1$-integrin and P-selectin appeared to colocalize on activated eosinophils, when investigated by immunofluorescence microscopy (83). The addition of soluble P-selectin to whole blood caused enhanced activation of $\alpha 4 \beta 1$-integrin on eosinophils and also enhanced eosinophil adhesion to vascular cell adhesion molecule-1 in vitro (83). Further investigations found that after whole-lung antigen challenge of patients with asthma, circulating eosinophils associated with P-selectin disappeared from the circulation, suggesting a migration of platelet-eosinophil complexes into the lungs (52). This hypothesis is supported by findings that demonstrate under flow conditions in the blood of patients with asthma, blocking antibodies directed against P-selectin, causes a decrease in eosinophil binding and clustering to activated endothelium (85). Indeed, in situ staining reveals platelets attached to intravascular eosinophils after allergen challenge in a murine model of allergic airways inflammation (13). Therefore, early contact-dependent interactions between platelets and eosinophils are likely to be important in subsequent eosinophil recruitment, since it is now recognized that platelet contact via platelet P-selectin with neutrophils is necessary for efficient neutrophil adhesion, and this has been visualized via intra-vital and multiphoton microscopy $(6,43$, 44, 93). Such events could be initiated through the increased preponderance of platelet-eosinophil complexes. Nevertheless, along with the direct physical interactions between platelets and eosinophils, platelets can also influence eosinophil function via inflammatory mediator release. The platelet-specific chemokine,
PF-4, is capable of accelerated eosinophil-endothelial adhesion due to upregulation of adhesion molecules $(14,94)$.

\section{PHARMACOLOGICAL STRATEGIES FOR MODULATING PLATELET-EOSINOPHIL INTERACTIONS}

The development of therapeutic strategies to inhibit plateleteosinophil interactions would be considered part of a larger research effort to modulate platelet function during inflammation (rather than solely platelets and eosinophils). Such a strategy is clearly nascent. Anti-platelet drugs (e.g., aspirin, $\mathrm{P}_{12}$ antagonists clopidogrel, and prasugrel) used in the prevention of thrombi in patients with cardiovascular disease have not been extensively tested in non-thrombotic diseases, and especially asthma, although prasugrel was reported to have a limited (if any) beneficial effect in patients with asthma (95). Other P2 $\mathrm{Y}_{12}$ antagonists had no effect of pulmonary leukocyte (including eosinophil) recruitment in a murine model of allergic airways inflammation (5). This would suggest that a dichotomy in platelet function exists between inflammatory responses pertinent to host defense, and platelet aggregation in response to vascular injury (4). Therefore, platelet activation and signaling pathways are likely to be separated and require a different anti-platelet pharmacy to be effective compared with established anti-platelet drugs used to inhibit the formation of thrombi. In this regard, the mechanisms of platelet activation that are necessary for pulmonary leukocyte (and eosinophil) recruitment in models of allergic and nonallergic inflammation have been shown to be platelet $\mathrm{P}_{2} \mathrm{Y}_{1}$ (5), and $\mathrm{P}_{2} \mathrm{Y}_{14}$ (96) dependent via signaling pathways involving Rho GTPases (RhoA, Rac-1) that are largely redundant during platelet activation in the context of hemostasis $(5,6)$.

Other strategies that inhibit processes associated with platelets (e.g., platelet P-selectin-dependent leukocyte recruitment) have gained traction. Bimosiamose, a small molecule antagonist to P-selectin, attenuated late asthmatic reactions following allergen challenge in mild asthmatics in a randomized, double-blind, placebo-controlled clinical cross over trial (97). Selectins are difficult structures to create effective small molecule antagonists against. Consequently, several drugs that inhibit the synthesis of PSGL-1 and therefore have the potential to suppress P-selectindependent eosinophil recruitment are being examined (98). These compounds have been reported to inhibit the synthesis of PSGL-1 under inflammatory conditions, rather than affecting expression at resting state, and might therefore provide an important safety benefit of not affecting the necessary immunosurveillance of the host (98). Heparin is known to inhibit P-selectin-dependent events, and a non-anticoagulant form of heparin ( $\mathrm{N}$-acetyl-de-Osulfated-heparin), has recently been reported to disrupt plateletdependent eosinophil recruitment in animal models (93).

Thus, there is a therapeutic potential in disrupting plateleteosinophil interactions, or steps of platelet activation that have consequence on eosinophil functions, to alter the pathology of diseases associated with eosinophilia. Furthermore, an expanding volume of research is uncovering molecules whose biological pathways might in the future lead to drug development, for 
example, platelet-derived: 5-HT (22), IL-33 (99), Dickkopf-1 (100), and CD154 (101).

\section{CONCLUSION AND IMPLICATIONS}

Evidence now demonstrates the importance of platelets and their interactions with eosinophils in allergic disease states, with a dichotomy in their activation that is distinct to the function of platelets during hemostasis. Further research into the relationship between platelets and eosinophils may yield novel targets for drug intervention in respiratory diseases characterized by eosinophilia, for example, atopic asthma, rhinitis, and AERD,

\section{REFERENCES}

1. Born GVR. Observations on the change in shape of blood platelets brought about by adenosine diphosphate. J Physiol (1970) 209:487-511. doi:10.1113/ jphysiol.1970.sp009176

2. Gear A, Polanowska-Grabowska R. The platelet shape change. In: Gresele P, Fuster V, Page C, Vermylen J, editors. Platelets in Thrombotic and Non Thrombotic Disorders. Cambridge: Cambridge University Press (2002). p. 319-37.

3. Smyth SS, Mcever RP, Weyrich AS, Morrell CN, Hoffman MR, Arepally GM, et al. Platelet functions beyond hemostasis. J Thromb Haemost (2009) 7:1759-66. doi:10.1111/j.1538-7836.2009.03586.x

4. Page CP. The involvement of platelets in non-thrombotic processes. Trends Pharmacol Sci (1987) 9:66-71. doi:10.1016/0165-6147(88)90120-4

5. Amison RT, Momi S, Morris A, Manni G, Keir S, Gresele P, et al. RhoA signaling through platelet $\mathrm{P} 2 \mathrm{Y} 1$ receptor controls leukocyte recruitment in allergic mice. J Allergy Clin Immunol (2015) 135:528-38. doi:10.1016/j. jaci.2014.09.032

6. Pan D, Amison RT, Riffo-vasquez Y, Spina D, Cleary SJ, Wakelam MJ, et al. P-Rex and Vav Rac-GEFs in platelets control leukocyte recruitment to sites of inflammation. Blood (2015) 125:1146-59. doi:10.1182/ blood-2014-07-591040

7. Clemetson KJ, Clemetson JM, Proudfoot AE, Power CA, Baggiolini M, Wells TN. Functional expression of CCR1, CCR3, CCR4, and CXCR4 chemokine receptors on human platelets. Blood (2000) 96:4046-54.

8. Joseph M, Gounni AS, Kusnierz JP, Vorng H, Sarfati M, Kinet JP, et al. Expression and functions of the high-affinity $\operatorname{IgE}$ receptor on human platelets and megakaryocyte precursors. Eur J Immunol (1997) 27:2212-8. doi:10.1002/eji.1830270914

9. Hasegawa S, Tashiro N, Matsubara T, Furukawa S, Ra C. A comparison of Fc Â RI-mediated RANTES release from human platelets between allergic patients and healthy controls. Int Arch Allergy Appl Immunol (2001) 125:42-7. doi:10.1159/000053852

10. Semple JW, Freedman J. Platelets and innate immunity. Cell Mol Life Sci (2010) 67:499-511. doi:10.1007/s00018-009-0205-1

11. Pitchford SC, Momi S, Baglioni S, Casali L, Giannini S, Rossi R, et al. Allergen induces the migration of platelets to lung tissue in allergic asthma. Am J Respir Crit Care Med (2008) 177:604-12. doi:10.1164/ rccm.200702-2140C

12. Cognasse F, Nguyen KA, Damien P, McNicol A, Pozzetto B, HamzehCognasse $\mathrm{H}$, et al. The inflammatory role of platelets via their TLRs and Siglec receptors. Front Immunol (2015) 6:83. doi:10.3389/fimmu.2015.00083

13. Pitchford SC, Momi S, Giannini S, Casali L, Spina D, Page CP, et al. Platelet $\mathrm{P}$-selectin is required for pulmonary eosinophil and lymphocyte recruitment in a murine model of allergic inflammation. Blood (2005) 105:2074-81. doi:10.1182/blood-2004-06-2282

14. Hayashi N, Chihara J, Kobayashi Y, Kakazu T, Kurachi D, Yamamoto T, et al. Effect of platelet-activating factor and platelet factor 4 on eosinophil adhesion. Int Arch Allergy Immunol (1994) 1:57-9. doi:10.1159/ 000236754

15. Lindemann S, Tolley ND, Dixon DA, McIntyre TM, Prescott SM, Zimmerman $\mathrm{GA}$, et al. Activated platelets mediate inflammatory signaling by regulated by controlling the relationship between these essential blood components.

\section{AUTHOR CONTRIBUTIONS}

All authors contributed to article research, writing, and editing.

\section{FUNDING}

The Sackler Institute of Pulmonary Pharmacology, King's College London, is generously funded by an endowment from the Dr. Mortimer and Theresa Sackler Foundation.

interleukin 1beta synthesis. JCell Biol (2001) 154:485-90. doi:10.1083/ jcb. 200105058

16. Denis MM, Tolley ND, Bunting M, Schwertz H, Jiang H, Lindemann S, et al. Escaping the nuclear confines: signal-dependent pre-mRNA splicing in anucleate platelets. Cell (2005) 122:379-91. doi:10.1016/j.cell.2005.06.015

17. Oliveira SHP, Lukacs NW. The role of chemokines and chemokine receptors in eosinophil activation during inflammatory allergic reactions. Braz J Med Biol Res (2003) 36:1455-63. doi:10.1590/S0100-879X2003001100002

18. Benveniste J, Henson PM, Cochrane CG. Leukocyte-dependent histamine release from rabbit platelets. The role of IgE, basophils, and a plateletactivating factor. J Exp Med (1972) 136:1356-77. doi:10.1084/jem.136.6.1356

19. Page C, Pitchford S. Platelets and allergic inflammation. Clin Exp Allergy (2014) 44:901-13. doi:10.1111/cea.12322

20. Idzko M, Pitchford S, Page C. The role of platelets in allergic airway inflammation. J Allergy Clin Immunol (2015) 135:1416-23. doi:10.1016/j. jaci.2015.04.028

21. Yasuba H, Chihara J, Kino T, Satake N, Oshima S. Increased releasability of platelet products and reduced heparin-induced platelet factor 4 release from endothelial cells in bronchial asthma. J Lipid Mediat (1991) 4:5-21.

22. Dürk T, Duerschmied D, Müller T, Grimm M, Reuter S, Vieira RP, et al. Production of serotonin by tryptophan hydroxylase 1 and release via platelets contribute to allergic airway inflammation. Am J Respir Crit Care Med (2013) 187:476-85. doi:10.1164/rccm.201208-1440OC

23. Joseph M, Auriault C, Capron A, Vorng H, Viens P. A new function for platelets: IgE-dependent killing of schistosomes. Nature (1983) 303:810-2. doi:10.1038/303810a0

24. Maccia CA, Gallagher JS, Ataman G, Glueck HI, Brooks SM, Bernstein IL. Platelet thrombopathy in asthmatic patients with elevated immunoglobulin E. J Allergy Clin Immunol (1977) 59:101-8. doi:10.1016/0091-6749(77)90210-X

25. Palma-Carlos A, Palma-Carlos M, Santos M, de Sousa JR. Platelet aggregation in allergic reactions. Int Arch Allergy Appl Immunol (1991) 94:251-3. doi:10.1159/000235374

26. Maestrelli P, Boschetto P, Zocca E, Crescioli S, Baroldi P, Mapp C, et al. Venous blood platelets decrease during allergen-induced asthmatic reactions. Clin Exp Allergy (1990) 20:367-72. doi:10.1111/j.1365-2222.1990.tb02795.x

27. Sullivan PJ, Jafar ZH, Harbinson PL, Restrick LJ, Costello JF, Page CP. Platelet dynamics following allergen challenge in allergic asthmatics. Respiration (2000) 67:514-7. doi:10.1159/000067466

28. Kowal K, Pampuch A, Kowal-Bielecka O, DuBuske LM, Bodzenta-Łukaszyk A. Platelet activation in allergic asthma patients during allergen challenge with Dermatophagoides pteronyssinus. Clin Exp Allergy (2006) 36:426-32. doi:10.1111/j.1365-2222.2006.02446.x

29. Taytard A, Guenard H, Vuillemin L, Bouvot J, Vergeret J, Ducassou D, et al. Platelet kinetics in stable atopic asthmatic patients. Am Rev Respir Dis (1986) 134:983-5. doi:10.1164/arrd.1986.134.5.983

30. Metzger W, Sjoerdsma K, Richerson H, Moseley P, Zavala D, Monick M, et al. Platelets in bronchoalveolar lavage from asthmatic patients and allergic rabbits with allergen-induced late phase responses. Agents Actions Suppl (1987) 21:151-9.

31. Jeffery PK, Wardlaw AJ, Nelson FC, Collins JV, Kay AB. Bronchial biopsies in asthma. Am Rev Respir Dis (1989) 140:1745-53. doi:10.1164/ ajrccm/140.6.1745 
32. Czapiga M, Gao JL, Kirk A, Lekstrom-Himes J. Human platelets exhibit chemotaxis using functional N-formyl peptide receptors. Exp Hematol (2005) 33:73-84. doi:10.1016/j.exphem.2004.09.010

33. Kowalska MA, Ratajczak MZ, Majka M, Jin J, Kunapuli S, Brass L, et al. Stromal cell-derived factor- 1 and macrophage-derived chemokine: 2 chemokines that activate platelets. Blood (2000) 96:50-7.

34. Kraemer BF, Borst O, Gehring EM, Schoenberger T, Urban B, Ninci E, et al. PI3 kinase-dependent stimulation of platelet migration by stromal cell-derived factor 1 (SDF-1). J Mol Med (2010) 88:1277-88. doi:10.1007/ s00109-010-0680-8

35. Petito E, Momi S, Gresele P. The migration of platelets and their interaction with other migrating cells. In: Gresele P, Kleiman NS, Lopez JA, Page CP, editors. Platelets in Thrombotic and Non-Thrombotic Disorders. (Vol. 1), Cham: Springer International Publishing AG (2017). p. 337-51.

36. Orida N, Feldman JD, Katz DH, Liu FT. IgE-mediated chemotaxis of rat basophilic leukemia cells towards specific antigen. J Exp Med (1983) 157:2166-71. doi:10.1084/jem.157.6.2166

37. Ishizuka T, Okajima F, Ishiwara M, Iizuka K, Ichimonji I, Kawata T, et al. Sensitized mast cells migrate toward the antigen: a response regulated by p38 mitogen-activated protein kinase and Rho-associated coiled-coilforming protein kinase. J Immunol (2001) 167:2298-304. doi:10.4049/ jimmunol.167.4.2298

38. Sawada J, Shimizu S, Tamatani T, Kanegasaki S, Saito H, Tanaka A, et al. Stem cell factor has a suppressive activity to IgE-mediated chemotaxis of mast cells. J Immunol (2005) 174:3626-32. doi:10.4049/jimmunol.174.6.3626

39. Svensson L, Rudin A, Wennerås C. Allergen extracts directly mobilize and activate human eosinophils. Eur J Immunol (2004) 34:1744-51. doi:10.1002/ eji.200324798

40. Svensson L, Redvall E, Björn C, Karlsson J, Bergin AM, Rabiet MJ, et al. House dust mite allergen activates human eosinophils via formyl peptide receptor and formyl peptide receptor-like 1. Eur JImmunol (2007) 37:1966-77. doi:10.1002/eji.200636936

41. Kuehn HS, Gilfillan AM. G protein-coupled receptors and the modification of FcepsilonRI-mediated mast cell activation. Immunol Lett (2007) 113:59-69. doi:10.1016/j.imlet.2007.08.007

42. Kuehn HS, Rådinger M, Brown JM, Ali K, Vanhaesebroeck B, Beaven MA, et al. Btk-dependent Rac activation and actin rearrangement following FcepsilonRI aggregation promotes enhanced chemotactic responses of mast cells. J Cell Sci (2010) 123:2576-85. doi:10.1242/jcs.071043

43. Sreeramkumar V, Adrover JM, Ballesteros I, Cuartero MI, Rossaint J, Bilbao I, et al. Neutrophils scan for activated platelets to initiate inflammation. Science (2014) 346:1234-8. doi:10.1126/science.1256478

44. Zuchtriegel G, Uhl B, Puhr-Westerheide D, Pörnbacher M, Lauber K, Krombach F, et al. Platelets guide leukocytes to their sites of extravasation. PLoS Biol (2016) 14:e1002459. doi:10.1371/journal.pbio.1002459

45. Bengtsson T, Frydén A, Zalavary S, Whiss PA, Orselius K, Grenegård M. Platelets enhance neutrophil locomotion: evidence for a role of P-selectin. Scand J Clin Lab Invest (1999) 59:439-49. doi:10.1080/00365519950185463

46. Kornerup KN, Salmon GP, Pitchford SC, Liu WL, Page CP. Circulating platelet-neutrophil complexes are important for subsequent neutrophil activation and migration. J Appl Physiol (2010) 109:758-67. doi:10.1152/ japplphysiol.01086.2009

47. Frydman GH, Le A, Ellett F, Jorgensen J, Fox JG, Tompkins RG, et al. Technical advance: changes in neutrophil migration patterns upon contact with platelets in a microfluidic assay. J Leukoc Biol (2017) 101:797-806. doi:10.1189/jlb.1TA1115-517RR

48. Rainger GE, Buckley C, Simmons DL, Nash GB. Cross-talk between cell adhesion molecules regulates the migration velocity of neutrophils. Curr Biol (1997) 7:316-25. doi:10.1016/S0960-9822(06)00155-2

49. Coyle A, Page CP, Atkinson L, Flanagan R, Metzger WJ. The requirement for platelets in allergen-induced late asthmatic airway obstruction. Eosinophil infiltration and heightened airway responsiveness in allergic rabbits. Am Rev Respir Dis (1990) 142:587-93. doi:10.1164/ajrccm/142.3.587

50. Keir S, Spina D, Page C. Bradykinin and capsaicin induced airways obstruction in the guinea pig are platelet dependent. Pulm Pharmacol Ther (2015) 33:25-31. doi:10.1016/j.pupt.2015.05.004

51. Benton AS, Kumar N, Lerner J, Wiles AA, Foerster M, Teach SJ, et al. Airway platelet activation is associated with airway eosinophilic inflammation in asthma. J Investig Med (2010) 58:987-90. doi:10.231/JIM. 0b013e3181fa02f7

52. Johansson MW, Han ST, Gunderson KA, Busse WW, Jarjour NN, Mosher DF. Platelet activation, P-selectin, and eosinophil $\beta 1$-integrin activation in asthma. Am J Respir Crit Care Med (2012) 185:498-507. doi:10.1164/rccm. 201109-1712OC

53. Pitchford SC, Riffo-Vasquez Y, Sousa A, Momi S, Gresele P, Spina D, et al. Platelets are necessary for airway wall remodeling in a murine model of chronic allergic inflammation. Blood (2004) 103:639-47. doi:10.1182/ blood-2003-05-1707

54. Speth C, Löffler J, Krappmann S, Lass-Flörl C, Rambach G. Platelets as immune cells in infectious diseases. Futur Microbiol (2013) 8:1431-51. doi:10.2217/fmb.13.104

55. Pleass RJ. Platelet power: sticky problems for sticky parasites? Trends Parasitol (2009) 25:296-9. doi:10.1016/j.pt.2009.04.002

56. McMorran BJ, Wieczorski L, Drysdale KE, Chan JA, Huang HM, Smith C, et al. Platelet factor 4 and Duffy antigen required for platelet killing of Plasmodium falciparum. Science (2012) 338:1348-51. doi:10.1126/science.1228892

57. Da’Dara AA, Skelly PJ. Schistosomes versus platelets. Thromb Res (2014) 134:1176-81. doi:10.1016/j.thromres.2014.09.032

58. Capron M, Capron A. Effector functions of eosinophils in schistosomiasis. Mem Inst Oswaldo Cruz (1992) 87:167-70. doi:10.1590/S007402761992000800025

59. Huang L, Appleton JA. Eosinophils in helminth infection: defenders and dupes. Trends Parasitol (2016) 32:798-807. doi:10.1016/j.pt.2016.05.004

60. Capron M, Joseph M. The low affinity receptor for IgE on eosinophils and platelets. Monogr Allergy (1991) 29:63-75.

61. Joseph M, Capron A, Ameisen JC, Capron M, Vorng H, Pancré V, et al. The receptor for IgE on blood platelets. Eur J Immunol (1986) 16:306-12. doi:10.1002/eji.1830160318

62. Chihara J, Nakajima S. Induction of hypodense eosinophils and nuclear hypersegmentation of eosinophils by various chemotactic factors and lymphokines in vitro. Allergy Proc (1989) 10:27-32. doi:10.2500/108854189778968515

63. Kameyoshi Y, Dorschner A, Mallet AI, Christophers E, Schroder JM. Cytokine RANTES released by thrombin-stimulated platelets is a potent attractant for human eosinophils. J Exp Med (1992) 176:587-92. doi:10.1084/ jem.176.2.587

64. Kameyoshi Y, Schröder J, Christophers E, Yamamoto S. Identification of the cytokine RANTES released from platelets as an eosinophil chemotactic factor. Int Arch Allergy Immunol (1994) 104:49-51. doi:10.1159/000236751

65. Burgers JA, Schweizer RC, Koenderman L, Bruijnzeel PL, Akkerman JW. Human platelets secrete chemotactic activity for eosinophils. Blood (1993) 81:49-55.

66. Chihara J, Hayashi N, Kakazu T, Yamamoto T, Kurachi D, Nakajima S. RANTES augments radical oxygen products from eosinophils. Int Arch Allergy Immunol (1994) 1:52-3. doi:10.1159/000236752

67. Raiden S, Schettini J, Salamone G, Trevani A, Vermeulen M, Gamberale $\mathrm{R}$, et al. Human platelets produce granulocyte-macrophage colony-stimulating factor and delay eosinophil apoptosis. Lab Invest (2003) 83:589-98. doi:10.1097/01.LAB.0000062851.71286.47

68. Nutten S, Papin J, Woerly G, Dunne D, MacGregor J, Trottein F, et al. Selectin and Lewis(x) are required as co-receptors in antibody-dependent cell-mediated cytotoxicity of human eosinophils to Schistosoma mansoni schistosomula. Eur J Immunol (1999) 29:799-808. doi:10.1002/ (SICI)1521-4141(199903)29:03<799::AID-IMMU799>3.3.CO;2-T

69. de Bruijne-Admiraal LG, Modderman PW, Von dem Borne AE, Sonnenberg A. P-selectin mediates Ca2+-dependent adhesion of activated platelets to many different types. Blood (1992) 80:134-42.

70. McCarty OJT, Tien N, Bochner BS, Konstantopoulos K. Exogenous eosinophil activation converts PSGL-1-dependent binding to CD18-dependent stable adhesion to platelets in shear flow. Am J Physiol Cell Physiol (2003) 284:C1223-34. doi:10.1152/ajpcell.00403.2002

71. Lee T, Lenihan DJ, Malone B, Roddy LL, Wasserman SI. Increased biosynthesis of platelet-activating factor in activated human eosinophils. J Biol Chem (1984) 259:5526-30.

72. Rohrbach MS, Wheatley CL, Slifman NR, Gleich GJ. Activation of platelets by eosinophil granule proteins. J Exp Med (1990) 172:1271-4. doi:10.1084/ jem.172.4.1271 
73. Maziero AM, Lorenzetti R, Donato JL, Lilla S, De Nucci G. Inhibition of human platelet aggregation by eosinophils. Life Sci (2013) 93:416-22. doi:10.1016/j.lfs.2013.07.012

74. Sakai T, Inoue S, Matsuyama T, Takei M, Ota H, Katagiri T, et al. Eosinophils may be involved in thrombus growth in acute coronary syndrome. Int Heart $J$ (2009) 50:267-77. doi:10.1536/ihj.50.267

75. Jiang P, Wang D, Ren Y, Cai J, Chen B. Significance of eosinophil accumulation in the thrombus and decrease in peripheral blood in patients with acute coronary syndrome. Coron Artery Dis (2015) 26:101-6. doi:10.1097/ MCA.0000000000000186

76. Lasser EC, Berry C, Kortman K. Diminished atherosclerotic arterial calcifications in asthma. A possible role for elevated endogenous heparin-like material. Allergy (1987) 42:549-52. doi:10.1111/j.1398-9995.1987.tb00381.x

77. Lu Y, Sjöstrand M, Malmhäll C, Rådinger M, Jeurink P, Lötvall J, et al. New production of eosinophils and the corresponding TH1/TH2 balance in the lungs after allergen exposure in BALB/c and C57BL/6 mice. Scand J Immunol (2010) 71:176-85. doi:10.1111/j.1365-3083.2009.02363.x

78. Perić A, Vojvodić D, Vukomanović-Đurđević B, Baletić N. Eosinophilic inflammation in allergic rhinitis and nasal polyposis. Arh Hig Rada Toksikol (2011) 62:341-8. doi:10.2478/10004-1254-62-2011-2120

79. Laidlaw TM, Boyce JA. Pathogenesis of aspirin-exacerbated respiratory disease and reactions. Immunol Allergy Clin North Am (2013) 33:195-210. doi:10.1016/j.iac.2012.11.006

80. Lellouch-Tubiana A, Lefort J, Simon MT, Pfister A, Vargaftig BB. Eosinophil recruitment into guinea pig lungs after PAF-acether and allergen administration. Modulation by prostacyclin, platelet depletion, and selective antagonists. Am Rev Respir Dis (1988) 137:948-54. doi:10.1164/ ajrccm/137.4.948

81. Pitchford SC, Yano H, Lever R, Riffo-Vasquez Y, Ciferri S, Rose MJ, et al. Platelets are essential for leukocyte recruitment in allergic inflammation. J Allergy Clin Immunol (2003) 112:109-18. doi:10.1067/mai.2003.1514

82. Wardlaw AJ, Jeffrey PK, Majumdar S, Dewar A, Anwar ARE, Walsh G, et al. Platelet adhesion to eosinophils. Am Rev Respir Dis (1992) 145:A664.

83. Johansson MW, Mosher DF. Activation of $\beta 1$ integrins on blood eosinophils by P-selectin. Am J Respir Cell Mol Biol (2011) 45:889-97. doi:10.1165/ rcmb.2010-0402OC

84. Laidlaw TM, Kidder MS, Bhattacharyya N, Xing W, Shen S, Milne GL, et al. Cysteinyl leukotriene overproduction in aspirin-exacerbated respiratory disease is driven by platelet-adherent leukocytes. Blood (2012) 119:3790-8. doi:10.1182/blood-2011-10-384826

85. Ulfman LH, Joosten DP, van Aalst CW, Lammers JW, van de Graaf EA, Koenderman L, et al. Platelets promote eosinophil adhesion of patients with asthma to endothelium under flow conditions. Am J Respir Cell Mol Biol (2003) 28:512-9. doi:10.1165/rcmb.4806

86. Mayadas TN, Johnson RC, Rayburn H, Hynes RO, Wagner DD. Leukocyte rolling and extravasation are severely compromised in P selectin-deficient mice. Cell (1993) 74:541-54. doi:10.1016/0092-8674(93)80055-J

87. De Sanctis GT, Wolyniec WW, Green FH, Qin S, Jiao A, et al. Reduction of allergic airway responses in P-selectin-deficient mice. J Appl Physiol (1997) 83:681-7.

88. Broide DH, Humber D, Sullivan S, Sriramarao P. Inhibition of eosinophil rolling and recruitment in P-selectin- and intracellular adhesion molecule1-deficient mice. Blood (1998) 91:2847-56.

89. Symon FA, McNulty CA, Wardlaw AJ. P- and L-selectin mediate binding of T cells to chronically inflamed human airway endothelium. Eur J Immunol (1999) 29:1324-33. doi:10.1002/(SICI)1521-4141(199904)29:04<1324::AIDIMMU1324>3.3.CO;2-U
90. Lukacs NW, John A, Berlin A, Bullard DC, Knibbs R, Stoolman LM. E- and P-selectins are essential for the development of cockroach allergeninduced airway responses. J Immunol (2002) 169:2120-5. doi:10.4049/ jimmunol.169.4.2120

91. Jawien J, Chlopicki S, Gryglewski RJ. Interactions between human platelets and eosinophils are mediated by selectin-P. Pol J Pharmacol (2002) 54:157-60.

92. Jawień J, Łomnicka M, Korbut R, Chłopicki S. The involvement of adhesion molecules and lipid mediators in the adhesion of human platelets to eosinophils. J Physiol Pharmacol (2005) 56:637-48.

93. Riffo-Vasquez Y, Somani A, Man F, Amison R, Pitchford S, Page CP. A Non-anticoagulant fraction of heparin inhibits leukocyte diapedesis into the lung by an effect on platelets. Am J Respir Cell Mol Biol (2016) 55:554-63. doi:10.1165/rcmb.2015-0172OC

94. Bruijnzeel PL, Kuijper PH, Rihs S, Betz S, Warringa RA, Koenderman L. Eosinophil migration in atopic dermatitis. I: increased migratory responses to $\mathrm{N}$-formyl-methionyl-leucyl-phenylalanine, neutrophil-activating factor, platelet-activating factor, and platelet factor 4. J Invest Dermatol (1993) 100:137-42. doi:10.1111/1523-1747.ep12462781

95. Lussana F, Di Marco F, Terraneo S, Parati M, Razzari C, Scavone M, et al. Effect of prasugrel in patients with asthma: results of PRINA, a randomized, double-blind, placebo-controlled, cross-over study. J Thromb Haemost (2015) 13:136-41. doi:10.1111/jth.12779

96. Amison RT, Arnold S, O’Shaughnessy BG, Cleary SJ, Ofoedu J, Idzko M, et al. Lipopolysaccharide (LPS) induced pulmonary neutrophil recruitment and platelet activation is mediated via the $\mathrm{P}_{2} \mathrm{Y}_{1}$ and $\mathrm{P} 2 \mathrm{Y}_{14}$ receptors in mice. Pulm Pharmacol Ther (2017) 45:62-8. doi:10.1016/j.pupt.2017.05.005

97. Beeh KM, Beier J, Meyer M, Buhl R, Zahlten R, Wolff G. Bimosiamose, an inhaled small-molecule pan-selectin antagonist, attenuates late asthmatic reactions following allergen challenge in mild asthmatics: a randomized, double-blind, placebo-controlled clinical cross-over-trial. Pulm Pharmacol Ther (2006) 19:233-41. doi:10.1016/j.pupt.2005.07.004

98. Kanabar V, Tedaldi L, Jiang J, Nie X, Panina I, Descroix K, et al. Base-modified UDP-sugars reduce cell surface levels of P-selectin glycoprotein 1 (PSGL-1) on IL-1 $\beta$-stimulated human monocytes. Glycobiology (2016) 26:1059-71. doi:10.1093/glycob/cww053

99. Takeda T, Unno H, Morita H, Futamura K, Emi-Sugie M, Arae K, et al. Platelets constitutively express IL-33 protein and modulate eosinophilic airway inflammation. J Allergy Clin Immunol (2016) 138:1395-403. doi:10.1016/j.jaci.2016.01.032

100. Chae WJ, Ehrlich AK, Chan PY, Teixeira AM, Henegariu O, Hao L, et al. The Wnt antagonist dickkopf-1 promotes pathological type 2 cell-mediated inflammation. Immunity (2016) 44:246-58. doi:10.1016/j. immuni.2016.01.008

101. Tian J, Zhu T, Liu J, Guo Z, Cao X. Platelets promote allergic asthma through the expression of CD154. Cell Mol Immunol (2015) 12:700-7. doi:10.1038/ cmi.2014.111

Conflict of Interest Statement: The authors declare that the research was conducted in the absence of any commercial or financial relationships that could be construed as a potential conflict of interest.

Copyright ( $(2017$ Shah, Page and Pitchford. This is an open-access article distributed under the terms of the Creative Commons Attribution License (CC BY). The use, distribution or reproduction in other forums is permitted, provided the original author(s) or licensor are credited and that the original publication in this journal is cited, in accordance with accepted academic practice. No use, distribution or reproduction is permitted which does not comply with these terms. 